\title{
THE ATLANTIC ACCORD: THE POLITICS OF COMPROMISE
}

C. P. MacDONALD* AND R. S. G. THOMPSON*

\begin{abstract}
The authors provide a critical overview of the Atlantic Accord signed on Feb 11, 1985 by the Government of Canada and the Government of Newfoundland. The paper was written prior to the introduction of the implementing legislation but nonetheless provides a critique of the.underpinning upon which the legislaton will rest.
\end{abstract}

\section{INTRODUCTION}

The purpose of this paper is to address a number of the more intriguing provisions of the Atlantic Accord ("Accord")' in order to assist legal practitioners in understanding the new regulatory regime governing the offshore area of Newfoundland and Labrador in respect of the exploration, development and production of hydrocarbons. Obviously, the implementing legislation will clarify to a great extent the practical detail of administrative and jurisdictional issues stemming from the Accord document. However, the detailed Accord provisions present the opportunity of commenting extensively on the approach and the structure of the envisaged regulatory regime.

The authors do not offer any particular insight into the drafters' plans for the implementing legislation other than to suggest, inter alia, certain issues that need to be clearly addressed in the legislation which is to be introduced within the year in both the House of Commons and the Newfoundland and Labrador House of Assembly.

This paper will not be a section-by-section analysis of the Accord; such an approach may be more useful after legislation has been drafted and introduced in the House of Commons and the Newfoundland Assembly. ${ }^{2}$ Instead, we wish to focus on a number of issues that need to be addressed, either by industry or governments in the near term, and perhaps prior to the introduction of the legislation.

A review of the legal question of ownership of the of fshore resources is in order, if only because the answer to that fundamental question in two separate reference cases, put to the Newfoundland Court of Appeal ${ }^{3}$ and the Supreme Court of Canada, ${ }^{4}$ respectively, provided an answer to the jurisdiction question and cleared the legal uncertainty to resolve the long standing Ottawa-Newfoundland dispute. The politics of Newfoundland

- Solicitor, Canterra Energy Ltd., Calgary.

* General Counsel, Department of Energy, Mines and Resources, Ottawa.

The authors' views are their own and do not necessarily reflect those of their respective employers. It is the authors' intention to provide an update to this paper subsequent to the introduction of the Atlantic Accord Implementation Act in the House of Commons and in the Newfoundland and Labrador House of Assembly.

1. Atlantic Accord signed February 11, 1985, by Prime Minister Mulroney and Premier Peckford in St. John's, Newfoundland.

2. Id. Section $\mathbf{5 7}$ provides for legislation to be introduced by each government within one year of the signing of the Accord.

3. Reference Re Mineral and Other Natural Resources of The Continental Shelf (1983) 145 D.L.R. (3d) 9 (Nfld. C.A.).

4. Reference Re The Seabed and Subsoil of The Continental Shelf Offshore Newfoundland (1984) 5 D.L.R. (4th) 385 (S.C.C.). 
and its impact on oil and gas development has been and, no doubt, will continue to be as crucial a determinant in the development of the offshore as will any legislative enactment. That the solution was the political one so long sought by Mr. Peckford is not surprising. That it follows in no sense on the constitutional answer would perhaps startle an observer. It is to hope, however, that the Canada-Newfoundland Atlantic Accord Implementation Act ("Accord Act") and establishment of the CanadaNewfoundland Offshore Petroleum Board ("Board") will provide the certainty and clarity needed by industry to proceed expeditiously with the development of the significant hydrocarbons in the Hibernia and prospective adjacent fields.

Our comment will review the judicial answers to the ownership question and address the nature of possible legislative techniques needed to provide the legal basis for the political solution reached by the Federal and Provincial governments.

The proposed regulatory model will provide this paper with most of our critical comments and we of fer some comparisons with three existing resource oriented boards: the Energy Resources Conservation Board of Alberta ("ERCB"), the National Energy Board ("NEB"), and the Canada-Nova Scotia Offshore Oil and Gas Board ("Can-NS Board").

The first recent constitutional development in respect of the offshore area is the decision of the Supreme Court of Canada in the Hibernia Reference, ${ }^{5}$ which deals specifically with the resource ownership and legislative jurisdiction on the continental shelf and, specifically, in the area of the Hibernia Discovery. The second is the decision of the Newfoundland Court of Appeal in Reference Re Mineral and Other Natural Resources of the Continental Shelf (the "Newfoundland Reference'), which deals both with the continental shelf and the territorial sea.

The question put before the Newfoundland Court of Appeal in the Newfoundland Reference was:?

Do the lands, mines, minerals, royalties or other rights, including the right to explore and exploit and the right to legislate, with respect to the mineral and other natural resources of the seabed and subsoil from the ordinary low-water mark of the Province of Newfoundland to the seaward limit of the continental shelf or any part thereof belong or otherwise appertain to the Province of Newfoundland?

The full answer given by the Court is divided into two parts: ${ }^{8}$

1. In respect of the lands, mines, minerals, royalties and other rights, including the right to explore and exploit and the right to legislate, with respect to the mineral and other natural resources of the seabed and subsoil from the ordinary low-water mark of the Province of Newfoundland to the seaward limit of the territorial sea, the answer is yes, subject to any interference with these rights which might arise from any valid legislation of the Parliament of Canada in respect of the territorial and inland waters.

2. In respect of the lands, mines, minerals, royalties and other rights including the right to explore and exploit and the right to legislate, with respect to the mineral and other natural resources of the seabed and subsoil from the seaward limit of the territorial sea to the seaward limit of the continental shelf, the answer is no.
5. Id.
6. Supra n. 3.
7. Id. at 12.
8. Id. at 9 (Headnote). 
It is clear from the judgment of the Newfoundland Court of Appeal that the territorial sea to which the judgment relates extends three nautical miles from the low-water mark of the Province of Newfoundland.

The judgment in the Newfoundland Reference generated two Notices of Appeal. A Notice of Appeal in respect of the continental shelf was filed in the Supreme Court of Canada by the Attorney General of Newfoundland, and a Notice of Appeal in respect of the territorial sea was filed by the Attorney General of Canada. At the time of writing, nothing further has been done in respect of the territorial sea question. For the time being at least, therefore, it is correct to treat Newfoundland as having legislative jurisdiction in respect of its bays and the territorial sea.

In respect of the continental shelf however, the constitutional issue is finally settled. The Supreme Court of Canada, in an unanimous judgment, has concluded that, as between Canada and Newfoundland, Canada has both the right to explore and exploit the mineral and other natural resources in the Hibernia area, and the legislative jurisdiction to make laws in relation to the exploration and exploitation of those minerals and other natural resources. ${ }^{9}$ It is in this context that the mutuality and parallelism of federal and Newfoundland legislation must be seen and any comparisons between the Newfoundland and Nova Scotia circumstances be considered.

There is a temptation to treat the Atlantic Accord and the Agreement dated March 2, 1982 between the Governments of Canada and Nova Scotia as if they solved similar problems in similar ways. In fact, although the political issues were the same, the legal solutions are quite different.

In respect of the area offshore Nova Scotia, there has been no judicial determination of the constitutional authority to make laws with respect to resources. Indeed, the governments agreed to leave the question unresolved and, as a result, it was necessary to create a complicated statutory mechanism of inter-delegation between federal and provincial ministers.

In the Newfoundland case, the situation is simpler. The principal constitutional question has been resolved. The drafters' challenge is first, to ensure that "by mutual and parallel legislation", 10 most of the powers that would otherwise be exercised by the federal and the provincial ministers in respect of the marine area beyond the low-water mark off Newfoundland are exercisable by the Canada/Newfoundland Offshore Petroleum Board and, secondly, to complete the framework of rules for decision-making constructed by the Atlantic Accord.

Mutuality and parallelism, therefore, have a quite different meaning in the one case than in the other. For Nova Scotia it was necessary, in order to create certainty and to minimize the risk of legal challenge to the actions of one minister or the other, that Parliament and the Legislative Assembly of Nova Scotia pass virtually identical laws in respect of

9. Supran. 4 at 418.

10. Supran. 1 at s. 1. 
resource management in the area offshore Nova Scotia. For Newfoundland, the area offshore Newfoundland beyond three miles is geographically outside the legislative competence of Newfoundland. All Canadian laws that apply there will be laws passed by Canada.

The governments have agreed that, to the extent that the Canada Oil and Gas Act ("COGA")" 11 and the Oil and Gas Production and Conservation Act ("OGPCA")"12 are consistent with the Accord, they will be retained in the legislation and the regulations implementing it. ${ }^{13}$ Clearly, the governments were anxious to reassure the oil and gas industry that the legal and administrative framework to which it had become accustomed would stay in place. It must be assumed that any mutual and parallel legislation passed by the Newfoundland Legislature will apply only to those areas within the legislative jurisdiction of Newfoundland. There is, therefore, no question in the Newfoundland case of the Legislature of Newfoundland passing a valid law in respect of oil and gas resources which are beyond the territorial sea adjacent to Newfoundland.

Incidentally, it would not appear necessary that legislation define the precise geographical area to which it applies, although it would perhaps be desirable to do so. It is worth noting that the Accord does not attempt to define the area to which it applies. ${ }^{14}$ It goes without saying that neither statute should purport to define an area for its application which is beyond the constitutional scope of that law-making body. Finally, it is plain that the governments have left to another day the question of where the lines between Newfoundland and the adjacent provinces and the Northwest Territories are to be drawn. ${ }^{15}$

\section{IMPLEMENTING LEGISLATION}

Each government has undertaken in the Accord that it will, within one year of the signing of the Accord, introduce the legislation necessary to implement the Accord and to support it as a government measure. ${ }^{16}$ That legislation clearly must include provisions replacing the $\mathrm{COGA}^{17}$ and the $\mathrm{OGPCA}^{18}$ in respect of the offshore area. At the time of writing, it seems reasonable to suppose that those provisions will differ from existing laws in at least the following respects:

1. they will identify the powers, duties and functions of the proposed Board;

2. they will include, by incorporation or otherwise, a royalty system to be determined by Newfoundland; and

3. they will effect the policy of the present federal government on the Crown share.

11. S.C. $1980-81-82-83$, c. 81 .

12. R.S.C. 1970 , c. $0-4$, as am.

13. Supran. 1 at s. 58 .

14. Id. at s. 68.

15. Id.

16. Id. s. 57.

17. Supran. 11.

18. Supran. 12. 
Federal legislation will also be required to extend federal laws to activity in the offshore. At present, federal laws do not apply generally to the area of the continental shelf, although a remedy is expected in the form of a federal law extending laws of general application to the continental shelf. In the meantime, it is necessary to examine federal statutes as Professor deMestral has done ${ }^{19}$ to determine whether a particular law applies in the offshore area. Canada has also agreed to apply appropriate provincial laws, including social legislation such as occupational health and safety legislation and other legislation designed to protect workers, to the offshore area. ${ }^{20}$ It is not clear what that provincial legislation will be. Presumably, it was not intended to be all provincial social legislation, but rather the provincial legislation dealing with occupational health and safety and legislation designed to protect workers and other similar legislation.

However, one device which Parliament may choose to adopt is to extend to the offshore area all Newfoundland laws not inconsistent with federal laws. If such a device is adopted, it will still be necessary to provide for the specific application of the worker health and safety laws of Newfoundland, since these would not necessarily be consistent with the Canada Labour Code.

Federal laws must also provide for the panoply of fiscal arrangements agreed to in the Accord, including the arrangements by which Newfoundland will receive the revenues of a corporate income tax, a sales tax, bonus payments, rentals, licence fees and such other forms of resource revenues "and provincial taxes of general application" as are consistent with the spirit of the Accord and as may be established from time to time. ${ }^{21}$

In a way, more interesting than the changes in law required by the Accord, is a review of the legislation which continues to apply unamended. Apart from laws replacing the Canada Oil and Gas Act and the Oil and Gas Production and Conservation Act and enacting the equivalent of the provincial Petroleum and Natural Gas Act, ${ }^{22}$ the Accord provides that all the federal and provincial legislation presently applicable to the management of the oil and gas resources in the of fshore will continue to apply. ${ }^{23}$ We submit that this was not intended to be an undertaking by each government never to amend this "other" legislation, but rather to be an acknowledgement that, except to the extent required by the Accord, each government was free to retain, amend or repeal its other legislation. It would appear, therefore, that the Canada Shipping Act $^{24}$ will continue to apply in the offshore area, and that the regulations under that Act will continue to be enforced by the Canadian Coastguard. It will remain for

19. A.L.C. deMestral "The Law Applicable to the Canadian East Coast Offshore" (1983) 21 Alta. Law Rev. 63.

20. Supra n. 1, s. 61 .

21. Id. ss. 37 and 57.

22. R.S.N. 1970, c. 294, as am.

23. Supran. 1, s. 58.

24. R.S.C. 1970 , c. S-9, as am. 
the new Board and the Coastguard to administer their operations in such a way as to minimize duplication and uncertainty.

The National Energy Board Act ${ }^{25}$ is clearly among other federal legislation which will continue to apply in the offshore area. Since, by virtue of the Act, the National Energy Board has jurisdiction in respect of pipelines extending from a province into the offshore area, there exists the clear possibility of friction between the proposed board and the NEB. Indeed, some lawyers argue that there is an overlap of jurisdiction over those pipelines at present because, under the Oil and Gas Production and Conservation Act, the Minister's permit is required for any work or activity in the offshore area and, therefore, theoretically at least, the companies are put at risk that they will be subjected to conflicting regulations and procedures in planning and carrying out pipeline construction. If it is determined that an overlap does exist between the authority of the new board and the National Energy Board, it should not be beyond the officials' creative abilities to minimize its consequences whether by a legislated or an administrative solution.

The provisions in the Accord dealing with the intention of both governments regarding legislation is set out in s. 36 and in ss. 57 through 62. The Accord states that those provisions of the Canada Oil and Gas Act, ${ }^{26}$ the Oil and Gas Production and Conservation Act, ${ }^{27}$ and their regulations which are inconsistent with the Accord will be repealed. Presumably, the Government of Newfoundland will seek to amend its laws regulating the offshore so that they are not inconsistent with the recent judicial pronouncements.

It should be pointed out that at the time of writing, significant revisions to COGA are being considered. It is likely that those proposed changes will be closely linked to the provisions in the CanadaNewfoundland Accord Act, although presumably, an amended COGA will continue to govern operations in the of fshore outside the geographic boundaries of the Atlantic Accord. The industry must be concerned about the "balkanization" of the present regime governing Canada Lands. The possibility exists of a similar arrangement with Nova Scotia modifying greatly the present Canada-Nova Scotia Board and that the remaining Maritime Provinces and the Province of British Columbia will seek similar arrangements. It is likely that the terms negotiated will be different in each case. The industry preference, not surprisingly, is to have as much consistency as possible for of fshore operations and a single window approach wherever possible. ${ }^{28}$ Some argue quite convincingly that industry must do business in a manner governed by local jurisdiction and laws and under local boards just as it does in the three western pro-

25. R.S.C. 1970 , c. N-6, as am.

26. Supran. 17.

27. Supran. 18.

28. For instance, a central registry of oil and gas "Interests" has significant economic and practical advantages as opposed to individual provincial and federal registries. 
vinces. ${ }^{29}$ The challenge for the Government of Canada, therefore, may be to satisfy the different political ambitions of the various provinces and territories while maintaining a common management system and common rules for explorers and developers wherever they operate in the offshore.

The techniques available to the draftsmen are few and not without some legal uncertainty as to their constitutionality. Briefly, interdelegation of strict constitutional authority is seemingly not possible without a constitutional amendment, but administrative delegation is apparently within the constitutional prerogative of the federal government. Professor Hunt makes the point succinctly: ${ }^{30}$

In 1950, legislative inter-delegation was found to run afoul of the Canadian constitution in the Nova Scotia Inter-delegation case. Since then, a line of cases has upheld the constitutionality of administrative delegation. Moreover, it has been held permissible for one level of government to incorporate by reference the laws or legislative standards of another level of government. It is even possible to adopt, in advance, amendments to the other government's legislation. When used together, the techniques of administrative delegation and anticipatory incorporation by reference can accomplish nearly everything one might wish to accomplish through legislative delegation.

As well, Canada can only inter-delegate what international law accords to her. Quaere what legal responsibilities fall upon Canada in the exercise of its sovereignty?31

Laurence Herman, in an article in the Canadian Bar Review in 1980, suggested two approaches for incorporation by reference: ${ }^{32}$

This could be done by providing, in the Federal Act, that all laws in force in the province to the extent they are not repugnant to or inconsistent with applicable federal laws will apply, as part of federal law, to acts or omissions occuring in relation to seabed resource activity in the submarine areas adjacent to the coast of Canada as defined. Alternatively, those specific provincial laws to be made applicable to the extent they are not in conflict with federal law, could be left for subsequent designation, presumably by Order in Council under the new Federal Act.

As Professor Herman later points out, ${ }^{33}$ his alternative solution provides some control by the Federal Cabinet over what provincial laws may be designated as governing of fshore activities.

If the Herman solution is not followed, the troublesome question remains as to the interpretation of the provision in s. 58 of the Accord which states: ${ }^{34}$

All other federal and provincial legislation which is presently applicable to the management of the oil and gas resources in the of fshore area will continue to apply.

29. Leo Barry, the Leader of the Official Opposition for the Province of Newfoundland and Labrador expressed this view at the Second Banff Conference on Natural Resources Law in April 1985.

30. Constance D. Hunt, "Recent Legal Developments Regarding Offshore Newfoundland", notes prepared for a presentation to the Natural Resources Subsection of the Canadian Bar Association in Calgary Feb. 13, 1985. p. 9. See also reference cases A.G. N.S. v. A.G. Can. (1951) S.C.R. 31 and A.G. Ont. v. V. Scott (1951) S.C.R. 137.

31. Herman, "The Need For a Canadian Submerged Lands Act: Some Further Thoughts on Canada's Offshore Mineral Rights Problem"' (1980) 58 Can. Bar. Rev. 519.

32. Id. at 542.

33. Id.

34. Supra n. 1, s. 61 . 
Professor deMestral's comprehensive article, ${ }^{35}$ earlier referenced, canvassed federal legislation which may be applicable to the of fshore. As indicated previously, his conclusion is that, in the absence of specific law extending federal law generally, there is considerable uncertainty as to what may or may not be applicable. The recent ad hoc approach to the extension of laws is, it is suggested, fraught with potential minefields. deMestral offers a two-fold solution for the law governing the continental margin: first, a general extension of all federal law; and, secondly, an incorporation by reference of provincial statutory and common law as it exists from time to time. He qualifies these suggestions in the following manner: ${ }^{36}$

(a) domestic law extended to the offshore must be "compatible with international law unless the law does not admit of such an interpretation";

(b) it may be wise to exclude the application of certain provincial laws to allow for greater certainty, although the constitutional concept of "paramountcy" may resolve any such conflict; and

(c) limit the incorporation of provincial laws to those not repugnant to or inconsistent with applicable federal law as was suggested by Professor Herman. ${ }^{37}$

Mendes has described the specific and complex problems associated with extending certain provincial statutes such as workers' compensation legislation to the offshore ${ }^{38}$ which will not be elaborated upon herein, suffice to say that particular overlapping jurisdictional issues must be addressed by administrative memoranda of understanding or clarified in the implementing legislation.

Professor deMestral also suggested that there is a need to clarify the jurisdiction of the courts in offshore matters. His suggestion that "provision should be made for exclusive jurisdiction of the Federal Court in its areas of specialized jurisdiction and for concurrent original jurisdiction of the provincial courts of the adjacent province over all other matters',39 would appear to be the intent of the Accord, with one major exception. It seems that s. 62 of the Accord limits the jurisdiction of the provincial courts to those laws extended to the offshore by Parliament. In other words, residual jurisdiction would rest with the Federal Court, as opposed to the provincial court, as had been suggested by deMestral.

Whatever the techniques employed by the drafters to effect the many and varied provisions of the Accord, there will remain some doubt about legislation that may not be specifically referenced by the incorporation of provincial law or which may not be extended by a general federal enabling statute. There will likely remain as well some constitutional doubt as

35. Supran. 19.

36. Id. at 80.

37. Supran. 31 at 542.

38. E.P. Mendes, "Newfoundland's Workers' Compensation Legislation: Constitutional and Conflict of Laws Issues Arising From Offshore Oil and Gas Exploration"' (1983) 21 Alta. Law Rev. 1.

39. Supran. 19 at 81. 
to the legality of what is done, but it is suggested that whatever methods are selected it will be better than the present uncertainty. The likelihood of a challenge to the constitutionality of the delegation of authority to the Board or the Province would seem remote to some. The offshore operator will want to live within the political compromise and get on with the exploration for and production of hydrocarbons. An offshore disaster like the Ocean Ranger ${ }^{40}$ and its resulting litigation could challenge shaky ad hoc political arrangements which are not fully within the ambit of proper legal authority. However, it should be pointed out that, from an administrative point of view, s. 63 of the Accord provides for memoranda of understanding between the Board and various federal and provincial government departments and agencies, to minimize potentially overlapping jurisdictional responsibilities and disputes. Section 63 specifically mentions environmental, safety and emergency measures as requiring such memoranda of understanding.

\section{PROPOSED REGULATORY REGIME}

\section{A. GENERAL}

There is only one example of a joint federal-provincial regulatory board to manage natural resource exploration and development in Canada. The Canada-Nova Scotia Board was set up pursuant to the Canada-Nova Scotia Agreement of March, 1982. Leaving that aside for the moment, all the other major regulatory boards in Canada ${ }^{41}$ have one legislative master and were set up either by legislation or regulation passed by, or pursuant to, powers granted by Parliament or by a provincial Legislature. Therefore, there is not much in the way of precedent to draw upon for the establishment of this Board.

Resource regulatory models and regimes in Canada have changed and matured over the past twenty to thirty years, as the industry developed or as new problems developed (e.g. the 1973 oil embargo by OPEC) and politicians reached for new answers and directions. Doern and Toner, in their recent book, devote a chapter to the recent history of energy regulation in Canada. ${ }^{42}$ The title of the chapter, "Energy Regulation: From Public Utility Policing to Developmental Bargaining", is instructive. The 1950's were characterized by a laissez faire attitude to regulation. For example, the ERCB in Alberta was established more to coordinate development than to dictate how industry should go about its business. The 1970's and 1980's have seen a highly interventionist approach to development on Canada Lands. Part of the reason for this development rests

40. In a press release from the Minister of Energy, Mines and Resources dated April 18, 1985 entitled "Government Releases Report on Recommendations of Ocean Ranger Royal Commission", the following comment was made: "With the signing of the Atlantic Accord on February 11, 1985, the governments of Canada and Newfoundland will share responsibility, through the new Canada-Newfoundland Offshore Petroleum Board, for the management of many of the areas covered by the Royal Commission's Inquiry".

41. Some of the major resource boards are: the National Energy Board, the Canada Oil and Gas Lands Administration, the Alberta Energy Resources Conservation Board, and the Ontario Energy Board, to name a few.

42. G. Bruce Doern and Glen Toner. The Politics of Energy, Metheuen, 1985 p. 398-450. 
with such relatively new governmental concerns as the environment and sovereignty control over natural resources, which, to some extent, reflect the political pressures of the day. Doern and Toner summarize the various ways in which regulation has developed over the years:43

\begin{abstract}
One can view regulation in several ways, each of which highlights different attributes and dilemmas. For example, one can visualize it in relation to governmental effort to affect conduct at the various "stages" in the production cycle of the industry. Thus regulation occurs at the point of initial exploration, at later development and production stages and in the transportation and marketing stage. Environmental regulation and the regulation of competition also enter the "energy" regulation cycle when viewed in this way. A second way to view regulation is to visualize the "types of behaviour" that regulation is attempting to affect, such as "policing" versus "developmental" behaviour. Regulation can be directed towards "preventing" things from happening, in short a policing function, or a public utility style of regulation designed to prevent abuses of monopoly power such as in the case of pipelines. Developmental regulation, on the other hand, involves an attempt to induce/require certain positive kinds of preferred behaviour as well.
\end{abstract}

It is suggested that the Board is attempting to swallow all of these concepts at once. It has the mandate to control development from initial exploratory activity, to production licensing, to collecting royalties and taxes. It controls or directs throughout all stages of the production cycle. Similarly, it has a policing function (s. 24(c) of the Accord provides the Board with final decision making authority over compliance functions such as "prosecution, notices and orders regarding of fences"), and a strong influence in "development behavior", including taking direction from both governments on such matters as Canada-Newfoundland benefits requirements. Thus, the dynamics of the regulation as suggested by Doern and Toner have the regulators acting "simultaneously as brokers on the one hand and advocates on the other". 44

We think it is useful to attempt to put in perspective what type of administrative body this Board may become. In attempting this analysis, reference is made to other resource regulatory bodies, particularly the Energy Resources Conservation Board ("ERCB'), the Canada-Nova Scotia Board and, to a limited extent, the National Energy Board ("NEB").

\title{
B. THE BOARD
}

The governments clearly intended the Board to be active, strong and independent. While the general membership of the Board will be appointed by each government (each government appoints three members and collectively appoints the chairman), the Accord encapsulates the desire of the parties that the members not act merely as nominees of the government appointing them, and that wherever possible, the Board should make its decisions by consensus. In view of the experiences of the Canada-Nova Scotia Board, it is entirely reasonable to suppose that the Board will handle the vast bulk, if not all, of its business without having to resort to a vote. The requirement that the Board should make decisions by consensus wherever possible seems to be a statement of political will, rather than of drafting instructions. ${ }^{45}$ Indeed, there are a number of
43. Id. at 400 .
44. Id.
45. Supran. 1, s. 12. 
provisions in the Atlantic Accord of this nature and it will be interesting to see whether the final federal bill will effect them by legislation individually or by incorporation of the entire Accord. Alternatively, the bill could treat these as statements of political preference which have the force of the political agreement of February 11 .

The same cannot be said of s. 13 of the Accord, which clearly obliges the Board to require applicants, permittees and licensees to file copies of all material concurrently with the Board and with both governments. This requirement is a potential irritant for those having business with the Board. However, it should be noted that the Accord does not propose that the legislation impose an obligation of triplication on those persons and it may be that the Board, in fulfilling its obligation, will find a reasonable administrative solution.

The Accord also requires that the Board inform the two governments of its decisions in a timely manner. ${ }^{46}$ This will not present a problem to the Board in respect of the decisions made at its meetings. However, it is inevitable that many, if not most, of the Board's decisions will be made at the staff level, just as is now the case with Ministerial decisions made by officials within the Canada Oil and Gas Lands Administration. Those decisions, it is submitted, are no less decisions of the Board for being taken by officials of the Board's bureaucracy. The Accord does not differentiate between decisions of greater or lesser importance, or between decisions taken by the Board at its meetings and its other decisions. Clearly, the legislation will answer those questions.

The Accord is terse about the financial underpinnings of the Board. It leaves many questions to be answered by the legislation or by administrative practice. The Accord provides that "the budget shall be sufficient to permit the Board to carry out its duties under the legislation implementing the Accord". ${ }^{47}$ What if it is insufficient? "Each government shall pay one-half of the approved annual costs of Board operations." 48 What if it doesn't? How are costs overruns to be dealt with? Are there deadlines for approval of the budget by each government? Will the Board have the power to borrow? Finally, in this connection, while the Accord requires that the implementing legislation afford both governments access to the Board's books and accounts for the purposes of audit, it is not clear how that legislation and the federal Auditor General Act ${ }^{49}$ will apply. The matter of the Auditor General's access to information has been the subject of recent litigation and, while the implementing legislation may give him access to the books and accounts of the Board, he would not be able to rely on s. 13(1) of the Auditor General Act which entitles him "to require and receive from members of the public service of Canada such information, reports and explanation as he deems necessary
46. Id. s. 11 .
47. Id. s. 18.
48. Id.
49. S.C. $1976-77$, c. 34 , as am. 


\section{...".50 Members of the Board are not to be public servants of Canada or} Newfoundland.51

The proposed Board may be instituted in various ways. It could, for example, be created by federal implementing legislation, as was the case with the Canada-Nova Scotia Board. Equally, it could be created by Newfoundland law. Again, it is possible to incorporate a body under federal and provincial law and, by statute, grant it the powers that devolve upon one Minister or another. But the dual parentage of the Board may require that its birth be seen clearly to be a joint effort and not to be more closely aligned with one jurisdiction than the other.

Two possibilities present themselves. First, the Board could be created by agreement of ministers, and it could then receive, by federal and provincial statutes, the variety of powers, duties and functions that were intended for it in the Atlantic Accord. An interesting precedent for this is the Roosevelt Campobello International Park Commission Act, ${ }^{52}$ where an agreement establishing a Commission to accept and arrange the summer home of President Roosevelt was set out as a schedule to the Act. The advantage of this solution for the Newfoundland offshore would be its neutrality as between the governments. The second alternative is to institute the Board under both federal and provincial law. The authors are not aware of any Canadian precedent for such a solution, although an interesting and comparable case can be found in the High Court of Australia. ${ }^{53}$

If either of these "neutral" alternatives is adopted, a series of interesting questions will arise which may be addressed by the legislation. For example, by virtue of s. 18 of the Federal Court Act, ${ }^{54}$ the Federal Court has exclusive jurisdiction to issue prerogative writs against any federal board, commission or other tribunal. A federal board, commission or other tribunal is defined as "any body or any person or persons having, exercising or purporting to exercise jurisdiction or powers conferred by or under an Act of Parliament of Canada, other than any such person or persons appointed under or in accordance with a law of a province or under s. 96 of the British North America Act, 1867'. The definition surely did not contemplate that a board, commission or tribunal would be created both under a federal and a provincial law. The issue whether the Federal Court has exclusive jurisdiction to apply certain remedies to the Board or whether it has none may, of course, be resolved by the implementing law.

Furthermore, although the Accord indicates that Board members are not to be federal or provincial public servants, ${ }^{55}$ it is not clear whether the Board's employees will be treated as employees of a federal or a provincial institution for the purposes of employment law.

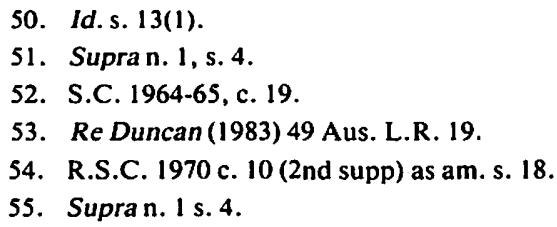


The long and sometimes bitter federal-provincial dispute that preceded the Accord is reflected in the numerous, complex dispute-resolution provisions of the document, which provide for the appointment of arbitration panels to handle those matters that cannot be resolved between the governments. For example, the appointment of the Chairman of the Board and the agreement on "fundamental decisions" 56 are to be resolved by arbitration failing the reaching of a consensus. ${ }^{57}$

\section{INDEPENDENCE AND JUDICIAL REVIEW}

Independence of the Board is recognized by both governments as important for the confidence of industry in order that the players in the offshore may make long range economic decisı ons with some assurance that the rules will not change. That objective will be achieved only if governments are not perceived as continually interfering with the day-to-day operation of the Board and if governments routinely accept Board decisions and recommendations (where necessary) without override or rejection.

Section 24 of the Accord gives the Board implicit authority to make final and binding decisions on a number of issues, including production licences, declarations of discovery, compliance functions, orders as to waste, oil and gas committee appellate functions, and the exercise of emergency powers, including the authority to initiate inquiries. The Board is also to have a residual authority to make final and binding decisions as to all other aspects of the regulation and management of offshore petroleum activities, ${ }^{58}$ other than fundamental decisions ${ }^{59}$ or specific directives ${ }^{60}$ from either government.

There are several questions about the actual power or authority accorded to the Board by s. 24 in the context of other related or similar powers existing through different federal statutes. For instance, compliance functions under such federal statutes as the Canada Shipping Act $^{61}$ and the Fisheries Act, ${ }^{62}$ which are delegated to Coastguard Officers or Fisheries Officers, could easily conflict with Board authority. Presumably, such overlapping provision will be accommodated by the memoranda of understanding provided for in $s .63$ of the Accord ${ }^{63}$ or by appropriate nonconflicting provisions in the implementing legislation itself.

Independence is also limited by the regulatory nature of the Board and its legal mandate. As pointed out earlier, final authority rests with the Board on matters set out in s. 24 of the Accord, including residual powers subject to certain Ministerial directives when a "public interest" matter

56. Id. s. 25 Note: "Fundamental decisions" are defined and set out in s. 25 . These decisions are to be made initially by the Board but require approval by both Governments.

57. Id. ss. 16 and 26.

58. Id. s. 24.

59. Id. s. 25.

60. Id. s. 33(a).

61. Supran. 24.

62. R.S.C. 1970 c. F-14, as am.

63. See text following note 40 , supra. 
arises. ${ }^{64}$ However, in making such final decisions, the Board will have to act in an adjudicative manner which will, of course, be subject to those rules of administrative law requiring such bodies to act in accordance with the rules of natural justice. Those final binding decisions of the Board must be arrived at under rules and procedures clearly set out and understood by those offshore industry participants appearing before the Board.

In this regard, the power of the Board apparently will be similar to many other energy regulatory bodies. For instance, the ERCB's powers have been described as follows: 65
As a creature of statute the Board is restricted to administrating its statutory jurisdic- tion and, in doing so, it discharges two basic functions. It performs an approving or ad- judicative function as required by individual statutory provisions which may include a Board public hearing.
It must also perform an advisory or investigative function when called upon to do so by the Lieutenant Governor in Council, or it may perform such a function on its own in- itiative.

Another limitation which follows from administrative law is the extent to which governments may provide directives to these boards: ${ }^{66}$

It must be remembered that a "direction" or "directive" is a piece of subordinate law making and, as such, must fulfill and not contradict statutory authority. Care will have to be taken that it is compatible with the spirit and intent of the enabling Act and authorized by it.

Finally, the new Charter of Rights and Freedoms impacts on how agencies created by government must behave as well as how decisions from such bodies may be reviewed by the courts: ${ }^{67}$

The option of the charter further broadens the constitutional bases of the court's powers to review the action of administration whether municipal, provincial, federal or independent agencies.

In each of these matters, as to the power and independence of the Board and the judicial review of its decisions, the peculiarity of the parentage of this Board continues to colour the nature of this "independent agency". By federal statute, it seemingly is a federal agency and, therefore, subject to review only in the Federal Court. On the other hand, its provincial heritage and delegated powers from the provincial government (which were in turn delegated to the Province from the federal government) give it a quasi-provincial nature which presumably argues for the Supreme Court of Newfoundland to have jurisdiction over its review.

Section 62 of the Accord purports to give the Federal Court the jurisdictional mandate over all matters in the offshore to the same extent as if the issue arose within their ordinary jurisdiction and similarly provides for Provincial Courts to have the jurisdictional mandate over those provincial laws extended by Parliament to the offshore. Quaere the abili-

64. Supran. 1, s. 33(a).

65. Bruni and Miller, "Practice and Procedure Before the ERCB" (1982) 20 Alta. L. Rev. 79.

66. Evans, et al., Administrative Law: Cases, Text and Materials (2nd ed. 1984) 602.

67. Id. at 15 . 
ty of Parliament to broaden the mandate of the Federal Court to the offshore entirely?68

\footnotetext{
The Supreme Court of Canada has imposed severe restrictions on the powers of the Parliament of Canada to confer upon the Federal Court of Canada a wide and exclusive jurisdiction in litigation involving the federal Crown or federal agency.

... The Supreme Court has protected the jurisdiction of the superior courts from an attempt by parliament to transfer powers to a specialized court with jurisdiction over many branches of federal public law. In the second line of cases, the Supreme Court of Canada has severely limited the power of provincial legislatures to reduce the jurisdiction of the superior courts by creating specialist administrative agencies to determine the rights of individuals under provincial legislation. The Supreme Court has also held that provincial legislation may not prohibit the superior courts from deciding whether a provincial agency has acted outside the limites of its legal powers.

Both these lines of cases constitutionally entrench aspects of the jurisdiction of the superior courts over disputes between the individual and the state. They curtail the ability of both levels of government to experiment with novel institutional arrangements to administer regulatory schemes and to determine the legality of administrative action.
}

One looks at the real authority still vested in the provincial and federal government through the delegated authority provision of s. 33(a). The control over "fundamental decisions" in s. 25 rests with the governments, and the power granted to the Board to initiate inquiries is qualified in s. 34(c), to the extent that the Board must accept the federal and provincial nominees to the Board. Section 33 is wider than the public policy directive power under the National Energy Board Act, ${ }^{69}$ in that it specifies that such highly politically-charged matters as "benefits" will be the subject of Ministerial directive and provides for an annual plan to be submitted to governments outlining the Board's exploration and development program for the year, which will be subject to a government veto. This authority alone could allow governments to influence most of the s. 24 decisions, particularly as to the issuance of production licences where the Board is supposed to have implicit and unchallenged authority. However, such directives are to be provided only when it is "in the public interest" or where "self-sufficiency and security of supply" is not being properly taken into consideration.

Time will tell the true degree of independence granted to the Board. Needless to say, its independence will likely grow with the confidence of governments in their decisions. In the meantime, industry will have to live with the understanding that both governments have the power and authority to enter into or influence most Board decisions, even some of those specified in s. 24, including the residual powers therein.

In the short term, it may be the federal government that holds the upper hand. The federal government has a vested override provision for the first five years and maybe longer, as a result of ss. 26 and 29 of the Accord. These provisions state that until there is self-sufficiency and security of supply, disputes between governments on "fundamental decisions" will be made by the federal minister. The determination on self sufficiency and security of supply will be made on a five-year basis and will be conclusive and binding on the parties. How that determination will be made and who will make it is a question that remains to be addressed in

68. Id. at 15 .

69. Supran. 25. 
[VOL. XXIV, NO. 1

the implementing legislation or administrative arrangements upon the formal establishment of the Board.

\section{SIMILARITIES WITH THE CREATION OF THE NATIONAL ENERGY BOARD}

It is interesting to compare the political environment surrounding the creation of the Board with the origins of the National Energy Board. The NEB was created out of a desire by the federal government to "depoliticize energy matters" 70 after the heated pipeline debate of 1956 and as a requirement to meet the quasi-regulatory framework of the $\mathrm{Na}$ tional Oil Policy of the time. The following early description of the NEB seems to fit the proposed Board at least in its infancy: ${ }^{71}$

Its decisions on export licences and construction certificates are subject to Cabinet approval. When combined with the NEB's statutory role as an advisor to the Minister of Energy, Mines and Resources and its role in carrying out studies of energy issues on its own volition or at the Minister's request, it is evident that the NEB was never a fully independent regulator. It was a quasi-regulator, quasi-manager of the industry operating with constant contact and interaction with the energy department.

As the Department of Energy, Mines and Resources grew in the 1970's (after 1973), it challenged the NEB's key role as the only regulator and as the chief adviser to the federal government. Eventually, with the establishment of Petro-Canada, the Northern Pipeline Agency and COGLA, the NEB is now only one of several key players in the overall federal management of energy resources. But noteworthy is the fact that the creation of the NEB in the context of bitter political debates, and its subsequent acceptance as a technically competent (if not fully independent) board, provided an environment that fostered a growing and stable industry for a time. ${ }^{72}$ Hopefully, the Canada-Newfoundland Board will be able to meet that same result after a few years.

\section{NOVA SCOTIA BOARD VERSUS NEWFOUNDLAND BOARD: A BRIEF COMPARISON}

Section 2(h) of the Accord states that one of the purposes of the Accord is to promote "within the system of joint management insofar as is appropriate, consistency with management regimes established for other offshore areas in Canada". Assuming that Nova Scotia is successful in renegotiating an agreement similar to the Accord, the resulting CanadaNova Scotia Board would have the same powers and authority. Leaving aside the question of how Nova Scotia would want to treat the question of jurisdiction in its offshore area (the Canada-Nova Scotia Agreement set it aside for forty years or more in the 1982 Agreement), there would be some built-in rivalry with two equally powerful boards in the East Coast of fshore.

It is important to examine the nature of the working relationship between the Canada-Nova Scotia and the Canada-Newfoundland Boards.

70. Supra n. 42 at 402 . See also chapter entitled "The Old Regulatory Regime: NEB and Energy Dynamics" at 402.

71. Id. at 403.

72. Id. at 404 . 
Matters such as geographic boundaries may be taken care of in the respective legislation, but what about such issues as the location of supply depots or communication facilities which, from an economic point of view, may be located in one province only. How will these politically sensitive matters be dealt with by the boards or more critically, by the respective provincial governments?

The development prospects of both the Hibernia oil field off Newfoundland and the Venture gas field off Nova Scotia and their corresponding adjacent fields would and does imply some economics of joint development plans (particularly as they presently have a common operator), although obviously the development of gas fields and oil fields have different problems associated therewith.

So far, these issues have been the heart of an intense but mostly littlepublicized rivalry between the Governments of Nova Scotia and of Newfoundland and Labrador. But as Doern and Toner point out, this rivalry influenced the signing of the Canada-Nova Scotia Agreement in 1982:73

The early arrangement of an agreement with the Nova Scotia Tories reflected a calculation on the part of the Buchanan government in the context of a depressed regional economy, that Nova Scotia could, by moving quickly, gain a larger share of of fshore oil business spin-offs, than its main regional competition, Newfoundland.

It is suggested that this rivalry will continue and will increase, particularly because of the common players in this development. Mobil (and its partners) as present operator of both Hibernia and Venture will, no doubt, want to make the most economical decision to proceed first with whichever development makes sense from a business point of view in time frames dictated by the economic context. The Government of Canada, no doubt, would like to see both developments proceed as quickly as possible. But if one project is to go before the other, then you will see both provincial governments become even more vocal as to their own particular project. Mobil and the Government of Canada (both through its own jurisdiction and in the boards governing the of fshore and through the national oil company, Petro-Canada) are caught in the middle. Similarly, the two offshore boards may find themselves being told to issue conflicting directives to the same company.

The offshore jurisdictional battles are far from over, and the separate boards created to oversee certain parts of Canada Lands will find themselves in conflict unless there is a strong commitment to undertake joint efforts for the development of the offshore.

\section{THE ALBERTA ENERGY RESOURCES CONSERVATION BOARD AS A ROLE MODEL}

The Newfoundland Government has used the ERCB as a reference in describing the type of Board they wish to see emulated in the CanadaNewfoundland Offshore Petroleum Board. The Minister responsible for the Petroleum Directorate, the Hon. William Marshall, after commen-

73. Supran. 42. at 473. 
ting on the physical environment parameters of oil and gas development in Alberta versus of fshore Newfoundland, said: ${ }^{74}$

However, in spite of this, the experience of the Alberta board, its basic principles of regulation and its model of technical competence, professionalism and integrity are something we can, and should emulate.

Mr. Marshall's remarks were made to a seminar sponsored by the Economic Council of Newfoundland and Labrador that examined the ERCB model in detail to determine if it would meet the requirement for a joint management board to regulate the development of the offshore. Papers $^{75}$ were delivered by Mr. Norm Strom, a member of the ERCB, Arnie Nielson who at the time was Chairman of the Canadian Petroleum Association and Professor Constance Hunt, Executive Director of the Canadian Institute of Resources Law. Each paper dealt with different perspectives of the ERCB and how the ERCB as a role model was useful and practical.

Arne Nielson concluded that the ERCB was an ideal model for the Accord Board:76

As a management system for Newfoundland and Labrador's offshore resources is developed, that system should be staffed with competent, non-partisan professionals. As our experience with the ERCB demonstrates time and time again this is the best possible foundation upon which to build material respect and understanding between industry and its regulators.

By the same token, the regulatory jurisdiction should be clearly spelled out so that there is minimal room for either industry or government to misunderstand the regulator's role. The ERCB has developed a nearly ideal model to use as the Newfoundland Offshore Agency is developed.

Professor Hunt's paper, on the other hand, suggested that there were significant problems, from a legal and constitutional point of view, in using the ERCB model without major changes. ${ }^{77}$ The nature of a joint ederal-provincial board will present many different sorts of problems than the ERCB has ever had to face: ${ }^{78}$

Furthermore, the ERCB is not an example of federal-provincial co-operation in resource management. If the body proposed for the Newfoundland of fshore includes both federal and provincial representatives, it is hard to see how the members will be able to retain the impartiality that characterizes the ERCB members especially in those situations where the two governments have conflicting goals.

The politicians' attraction to the ERCB as a role model is the respect that the Board has garnered from the industry and the general public in Alberta. However, it is suggested that this integrity and respect was earn-

74. Hon. William Marshall, keynote address to a Seminar on "Management of Oil and Gas Resources" held in Saint John's Newfoundland on November 20, 1984 sponsored by Economic Council of Newfoundland and Labrador. See Proceedings published by Council for this seminar at 51 .

75. Id. See Proceedings for the Seminar published by Economic Council of Newfoundland and Labrador. The titles of the papers presented were: N.A. Strom, "The Role of the Alberta Energy Resources Conservation Board (ERBC) in the Management of Alberta's Energy Resources"; A.R. Nielson, "The Experiences of the Oil and Gas Industry Re the ERCB and Possible Lessons to be Applied to the Newfoundland Case", and C.D. Hunt, "Legal and Constitutional Overview of the Application of the ERBC to the Newfoundland Offshore".

76. Id. at 28 of the Proceedings.

77. Most of these considerations have been discussed earlier in this paper: see text accompanying notes 19, 30, 31, 32 and 38 supra.

78. Supra n. 75 at 44. 
ed over a long period of time and not without some criticism, particularly from the public at large who still complain from time to time that the ERCB is merely a rubber stamp of industry.

The role of the public before the ERCB is likely another distinction from that which can be expected before the Accord Board. The ERCB grants standing to persons whose rights may be "directly and adversely affected"' by an application, and its constating statute provides that those persons who come within the statutory definition of "local intervener" may receive an "award of costs" for the costs incurred in participating in the ERCB decision-making process. ${ }^{79}$ Normally, the ERCB orders that the "local interveners' costs" are to be paid by the applicant, and such awards are subject to ERCB review and to an appeal to the Alberta Court of Appeal on an error of law or jurisdiction. ${ }^{80}$ The Accord is silent on the standing to be given to members of the public before the Board. Section 34 of the Accord envisages public hearings, but the Accord does not set out a role for the public. Nor does it state whether individuals directly affected by the proposed development (e.g. fishermen whose fishing grounds may be directly impacted) will have standing to participate in the decision-making process or be entitled to receive financial assistance, or "interveners' costs", for doing so.

Dr. George Govier's appointment to advise governments on the makeup of the new Board clearly signals that both governments like the ERCB as a role model. ${ }^{81} \mathrm{Dr}$. Govier served many years as Chairman of the ERCB ${ }^{82}$ and will no doubt bring a good deal of practical advice to the creators of this new Board. We are, therefore, likely to see a modified version of the ERCB in the Canada-Newfoundland Offshore Petroleum Board.

\section{CONCLUSIONS}

Considerable progress has been made in the last three years toward a regime in the area offshore Newfoundland and Labrador to create more permanence and certainty for those who invest in exploration and development. The constitutional decisions and the political settlement embodied in the Atlantic Accord have defined the ground rules for the future. We would be deceiving ourselves, however, to suppose that all the answers are now known about the rights and obligations of the governments and energy companies. The Atlantic Accord does not pretend to be a compendium of those rights and duties. The answers must await the tabling of the Accord legislation. At the time of writing - May 1985we can only speculate as to whether and how the questions will be answered in the legislation. How, for example, will it address the manner in which Newfoundland will control the mode of development, bearing in

79. The Energy Resources Conservation Act, R.S.A. 1980 c. E-11, as am., ss. 29(2) and 31.

80. Id. ss. $31(3)$ and 44.

81. Dr. George Govier, former Chairman of the Alberta Energy Resources Conservation Board, was appointed on April 18,1985 as advisor to both Governments on matters relating to the establishment, organization and staffing of the Canada-Newfoundland Offshore Petroleum Board.

82. $1962-1978$. 
mind that the development plan lives not in the law but as part of the understood jargon between industry and government? Will the royalty which would be required of Canada under the Law of the Sea Convention become Newfoundland's obligation? The Accord is silent although an argument would appear to be well-founded that the persons receiving royalties for production should be liable for the LOS royalty.

Will the governments opt for openness in enacting that the directives issued to the new Board are to be published? Or will some directives remain secret? Stay tuned. It is as important to lawyers in the energy business to have these questions answered as it was to know who shot J.R. 